\title{
Assessment of Physical Fitness in Medical Students
}

\author{
Chaudhary $\mathrm{S}^{1}$, Khadka $\mathrm{R}^{2}$, Pandey $\mathrm{KR}^{2}$, Paudel $\mathrm{BH}^{2}$, Shah $\mathrm{GJ}^{3}$, Chaudhary $\mathrm{H}^{1}$
}

\begin{abstract}
Introduction: Physical activity promotes cerebral blood flow during cognitive tasks and possibly enhances performance. It is relevant to find relationship between post exercise recovery heart rate (RHR) and resting pulse rate in medical students. Aims: To assess physical fitness in medical students. Methods: In this cross-sectional study, 57 consenting healthy medical students, age 1730 years, underwent 3-Minutes Step Test to assess their physical fitness. Students were divided into four fitness groups based on RHR; good ( $n=9, R H R=50-84$ bpm), satisfactory $(n=17, R H R=88-100$ bpm), poor ( $=12, R H R=102-107$ bpm), and very poor ( $n=19$, $\mathrm{RHR}=111-157 \mathrm{bpm}$ ) groups. The groups were compared using one-way ANOVA. A $p<0.05$ was considered statistically significant. Results: Results showed that there were few numbers of students who fall in good fitness group ( $n=9$, Resting pulse rate mean $72.00 \pm 9.29)$ in comparison to satisfactory fitness group $(n=17$, Resting pulse rate mean $(68.35 \pm 5.95)$, poor fitness group ( $n=$ 12 , Resting pulse rate mean $75.67 \pm 6.88$ ) and very poor fitness group ( $n=19$, Resting pulse rate mean 78.89 \pm 7.67$)$. The level of significance between satisfactory fitness group and very poor fitness group, $p<0.05$ was statistically significant. Conclusion: Most of the medical students fall under very poor fitness group. Satisfactory fitness group have less resting pulse rate in compare to very poor fitness group of medical students.
\end{abstract}

Keywords:Beats Per Minute, Blood Pressure, Body Mass Index, Heart rate, Physical Fitness, Pulse rate

\section{Authors:}

1. Mr. Sailesh Chaudhary

2. Dr. Rita Khadka

3. Dr. Karishma Rajbhandari Pandey

4. Dr. Bishnu Hari Paudel

5. Mr. Gaurav Jung Shah

6. Mr. Hiramani Prasad Chaudhary

${ }^{1}$ Department of Physiology, Nepalgunj Medical College, Chisapani, Banke

${ }^{2}$ Department of Physiology, BPKIHS, Dharan

${ }^{3}$ Department of Community Medicine, Chisapani, Banke

\section{Address for Correspondence:}

Mr. SaileshChaudhary

Department of Physiology

Nepalgunj Medical College

Chisapani, Banke

Email: saileshchaudhary666@gmail.com

\section{INTRODUCTION}

Physical fitness is linked to the person's capability to do physical activity. ${ }^{1}$ Fitness is divided into health and skill related components consists of cardiorespiratory endurance, muscular endurance, muscular strength, and flexibility. ${ }^{1}$ Physical Fitness Index (PFI) is one of the important criteria to assess the cardiopulmonary efficiency of a subject.2,3,4 PFI can be measured by three minutes step test. It is good measurement of fitness and a person's ability to recover after a strenuous exercise. ${ }^{5}$ The more quickly the heart rate returns to resting, the better is the physical fitness level of shape the person. ${ }^{6}$ Physical fitness has been reported to be a life style related factor predicting future incidence of dementia and cognitive impairment. ${ }^{7}$ A recent review noticed that executive control function and general measures of cognition are particularly strong correlates of physical functioning. ${ }^{8}$

\section{METHODS}

The study was conducted on healthy MBBS male and female medical students in the laboratory, Department of Physiology, Chisapani, Banke, Nepal.

Duration of study: 6 months $\left(31^{\text {st }}\right.$ August to $31^{\text {st }}$ December 2020)

Type of study: Cross sectional study

\subsection{SUBJECTS}

1.2 Sample size: 57 


\subsection{Sampling technique:}

Purposive sampling method was applied to select the subjects from MBBS students fulfilling inclusion \& exclusion criteria of the study were enrolled in the study.

\subsection{Inclusion criteria}

- Healthy young adults (MBBS students)

- $\quad$ Age from 17 to 25 years

\section{5 Exclusion criteria}

- Subjects with locomotors and musculoskeletal disorder

- $\quad$ Subjects with cardiovascular, respiratory and endocrine disorders and any other disorders affecting autonomic nervous system

- $\quad$ Subjects with a history of alcohol abuse, use of neurotoxic drugs or agents

- Subjects on regular medication

\section{6 Healthy subject definition/criteria}

Subjects who did not have any clinical history were considered as apparently healthy. Their health status was assessed through questionnaires, which assessed their medical history and physical health status along with measurement of cardiorespiratory variables.

\section{DETAILS OF RECORDING PROCEDURE}

\section{1) Measurement of Anthropometric Variables}

- $\quad$ Age was taken in complete years. It is height in meter $(\mathrm{m})$, weight in kilogram $(\mathrm{kg})$ were taken after taking off the shoes.

- $\quad$ BMI $\left(\mathrm{kg} / \mathrm{m}^{2}\right)$ was calculated for all of them from the obtained height and weight.

\section{2) Measurement of Cardiorespiratory Variables}

- For the cardiovascular variables pulse rate (bpm), systolic and diastolic blood pressures $(\mathrm{mm} \mathrm{Hg}$ ) were measured using standard procedure in sitting position at relaxed condition.

- $\quad$ Respiratory rate (breaths/min) was measured using stethograph.

- $\quad$ Pulse rate was detected by three finger method. In this method, three fingers (index, middle and ring) were used. The three fingers were placed over the radial artery on the wrist \& the pulse was taken by gently pressing the vessel against the head of radial bone.

\section{3) Recording Procedure of 3-Minute Step Test}

- The test was conducted using a bench $13^{\prime \prime}$ inches height.

- The test was done after 10 minutes rest in resting position.

- $\quad$ The subjects performed stepping cycle of four-step cadence (up-up-down-down).

- The subjects performed the test steps-ups for three minutes.

\section{Calculation of Physical Fitness Score}

After completion of the 3-Minute Step Test, the subject was asked to stand. After five seconds, his/her heart rate (pulse rate) was recorded for fifteen seconds and multiplied by four. This measured HR/ PR was considered as recovery heart rate of the subject.

Physical fitness scores were calculated depending upon the recovery heart rate of the subject in 3-Minutes Step Test. Calculation of physical fitness score was done by following the guidelines published by Young Man's Christian Association (YMCA).

Table I and II illustrated the age-adjusted standards based on guidelines published by YMCA. There was slight modification made in YMCA guideline for division of students into 4 groups in the present study (Table: III \&IV)

\begin{tabular}{|c|c|c|c|c|c|c|}
\hline $\begin{array}{c}\text { Category of } \\
\text { fitness }\end{array}$ & $\begin{array}{l}18-25 \\
\text { yrs. }\end{array}$ & $\begin{array}{l}26-35 \\
\text { yrs. }\end{array}$ & $\begin{array}{l}36-45 \\
\text { yrs. }\end{array}$ & $\begin{array}{l}46-55 \\
\text { Yrs. }\end{array}$ & $\begin{array}{c}56-65 \\
\text { yrs. }\end{array}$ & $\begin{array}{l}65+ \\
\text { yrs. }\end{array}$ \\
\hline Excellent & $50-76$ & $51-76$ & $49-76$ & $56-82$ & $60-77$ & $59-81$ \\
\hline Good & $79-84$ & $79-85$ & $80-88$ & $87-93$ & $86-94$ & $87-92$ \\
\hline $\begin{array}{l}\text { Above } \\
\text { Average }\end{array}$ & $88-93$ & $88-94$ & $92-88$ & $95-101$ & $97-100$ & $94-102$ \\
\hline Average & $95-100$ & $96-102$ & $100-105$ & $103-111$ & $103-109$ & $104-110$ \\
\hline $\begin{array}{l}\text { Below } \\
\text { Average }\end{array}$ & $102-107$ & $104-110$ & $108-113$ & $113-119$ & $111-117$ & $114-118$ \\
\hline Poor & $111-119$ & $114-121$ & $116-124$ & $121-126$ & $119-128$ & $121-126$ \\
\hline Very poor & $124-157$ & $126-161$ & $130-163$ & $131-159$ & $131-154$ & $130-151$ \\
\hline
\end{tabular}

Table I: Recovery Heart Rate ratings (BPM) for Men, Based on Age (YMCA protocol)

\begin{tabular}{|c|c|c|c|c|c|c|}
\hline $\begin{array}{l}\text { Category } \\
\text { of fitness }\end{array}$ & 18-25yrs & 26-35yrs & $36-45 y r s$ & $46-55 y r s$ & 56-65yrs & $65+y r s$ \\
\hline Excellent & $52-81$ & $55-80$ & $51-84$ & $63-91$ & $60-92$ & $70-92$ \\
\hline Good & $85-93$ & $85-92$ & $89-96$ & $95-103$ & $97-103$ & $96-101$ \\
\hline $\begin{array}{l}\text { Above } \\
\text { Average }\end{array}$ & $96-102$ & 95-101 & $100-104$ & $106-111$ & $106-111$ & $104-111$ \\
\hline Average & $104-110$ & $104-110$ & $107-112$ & $113-118$ & $113-118$ & $116-121$ \\
\hline $\begin{array}{l}\text { Below } \\
\text { Average }\end{array}$ & $113-1120$ & $113-119$ & $115-120$ & $119-127$ & $119-127$ & $123-126$ \\
\hline Poor & $122-131$ & $122-129$ & $124-132$ & $129-135$ & $129-135$ & $128-133$ \\
\hline $\begin{array}{l}\text { Very } \\
\text { poor }\end{array}$ & $135-169$ & $134-171$ & $137-171$ & $141-174$ & $141-174$ & $135-155$ \\
\hline
\end{tabular}

Table II: Recovery Heart Rate ratings (BPM) for women, Based on Age (YMCA protocol)

In our study, the physical fitness level given by YMCA was 
modified into four groups based on the recovery heart rate after the sub-maximal exercise. The modified fitness level assigned were:

Fitness level $1=$ Good

Fitness level 2 = Satisfactory

Fitness level 3 = Poor

Fitness level 4 = Very Poor

The details about the modification is illustrated in the following table III and IV.

\begin{tabular}{|ccc|}
$\begin{array}{c}\text { Fitness level assigned } \\
\text { for the present study } \\
\text { groups }\end{array}$ & $\begin{array}{c}\text { Fitness category } \\
\text { assigned by YMCA }\end{array}$ & $\begin{array}{c}\text { Recovery Heart Rate } \\
\text { (BPM) for 18-25 yrs. of } \\
\text { age (male) }\end{array}$ \\
\hline Good fitness level & Excellent & $50-76$ \\
Satisfactory fitness level & Good & $79-84$ \\
\hline Poor fitness level & Below average & $88-93$ \\
& Average & $95-100$ \\
Very poor fitness level & Poor & $111-119$ \\
\hline & Very poor & $124-157$ \\
\hline
\end{tabular}

Table III: Modification of category of physical fitness level and scores given by YMCA that was used for the present study for male subjects

\begin{tabular}{|ccc|}
$\begin{array}{c}\text { Fitness level assigned } \\
\text { for the present study } \\
\text { groups }\end{array}$ & $\begin{array}{c}\text { Fitness category } \\
\text { assigned by } \\
\text { YMCA }\end{array}$ & $\begin{array}{c}\text { Recovery Heart Rate (BPM) for } \\
\mathbf{1 8 - 2 5} \text { yrs. of age (female) }\end{array}$ \\
\hline Good fitness level & $\begin{array}{c}\text { Excellent } \\
\text { Good }\end{array}$ & $52-81$ \\
\hline $\begin{array}{c}\text { Satisfactory fitness } \\
\text { level }\end{array}$ & $\begin{array}{c}\text { Above Average } \\
85-93\end{array}$ \\
\hline Poor fitness level & Average & $96-102$ \\
\hline Velow average & $104-110$ \\
\hline & Poor & $113-120$ \\
\hline
\end{tabular}

Table IV: Modification of category of fitness level and scores given by YMCA that have been used for the present study for female subjects

\section{Physical Fitness Variables:}

$>\quad$ Physical Fitness Index and Recovery heart rate (beat/ $\min$ ) were recorded.

\section{Statistical analysis}

The statistical test was applied based on distribution of observations. Statistical analysis was done using statistical software SPSS version 21.0 (SPSS INC, Chicago, ILL, USA).

\section{Intergroup comparison}

The anthropometric and cardiorespiratory variables were normally distributed. Thus, were analyzed using parametric on way ANOVA followed by Post-Hoc Bonferroni tests.

The data are expressed as mean \pm SD for normally distributed data and median (interquartile range) for non-normally distributed data. The $p<0.05$ will be considered statistically significant.

\section{RESULTS}

\section{General characteristics of the healthy young medical students}

\section{Physical fitness variables}

All students were categorized into four groups based on the recovery HR measured/ calculated during their physical fitness test. The YMCA guidelines with some modification was used to categorize students into four physical fitness groups; good, satisfactory, poor and very poor fitness (table III\&IV).

\begin{tabular}{|c|c|c|c|c|c|}
\hline $\begin{array}{l}\text { Physical } \\
\text { fitness levels }\end{array}$ & $\begin{array}{c}\text { Recovery HR } \\
\text { Mean } \pm \text { SD } \\
(n=57)\end{array}$ & $\begin{array}{c}\text { Calculated } \\
\text { VO }_{2} \max \\
\text { Mean } \pm \text { SD } \\
(n=57)\end{array}$ & $\begin{array}{l}\text { Number } \\
\text { of medical } \\
\text { students } \\
\text { (\%) }\end{array}$ & Male & Female \\
\hline Good & $87.33 \pm 4.24$ & $60.15 \pm 15.52$ & $(1 \Theta \%)$ & 4 & 5 \\
\hline Satisfactory & $98.00 \pm 6.55$ & $58.47 \pm 15.84$ & $(30 \%)$ & 9 & 8 \\
\hline Poor & $110.92 \pm 5.98$ & $53.97 \pm 14.06$ & $\begin{array}{c}12 \\
(21 \%)\end{array}$ & 7 & 5 \\
\hline Very poor & $\begin{array}{c}128.42 \pm \\
10.78\end{array}$ & $48.26 \pm 7.54$ & $\begin{array}{c}19 \\
(33 \%)\end{array}$ & 9 & 10 \\
\hline & Total & & $\begin{array}{c}57 \\
(100 \%)\end{array}$ & 29 & 28 \\
\hline
\end{tabular}

Table 5: Physical fitness levels of medical students on the basis of recovery heart rate

\section{Comparison of general characteristics among four fitness groups}

\section{A) Anthropometric variables}

Comparison of anthropometric variables among four fitness groups showed no statistical differences (table VI).

\begin{tabular}{|c|c|c|c|c|c|}
\hline & & Groups & Mean \pm SD) & & \\
\hline Variables & $\begin{array}{l}\text { Good } \\
\text { fitness } \\
(n=9)\end{array}$ & $\begin{array}{l}\text { Satisfactory } \\
\text { fitness level } \\
\quad(n=17)\end{array}$ & $\begin{array}{c}\text { poor fitness } \\
\text { level } \\
(n=12)\end{array}$ & $\begin{array}{c}\text { Very poor } \\
\text { fitness level } \\
(n=19)\end{array}$ & $\begin{array}{l}\text { Over all } \\
\text { p-value }\end{array}$ \\
\hline Age(years) & $\begin{array}{c}20.78 \pm \\
1.56\end{array}$ & $20.94 \pm 0.89$ & $20.67 \pm 0.89$ & $20.79 \pm 1.44$ & 0.945 \\
\hline Height(m) & $\begin{array}{l}1.63 \pm \\
0.0711\end{array}$ & $1.68 \pm 0.086$ & $\begin{array}{l}1.68 \pm \\
0.0919\end{array}$ & $1.65 \pm 0.0813$ & 0.412 \\
\hline Weight(kg) & $\begin{array}{c}56.00 \pm \\
7.16 \\
21.18 \pm\end{array}$ & $61.18 \pm 9.24$ & $59.92 \pm 9.02$ & $58.26 \pm 8.58$ & 0.499 \\
\hline $\mathrm{BMI}\left(\mathrm{kg} / \mathrm{m}^{2}\right)$ & $\begin{array}{l}21.101 \\
3.27\end{array}$ & $21.73 \pm 3.44$ & $21.13 \pm 1.99$ & $21.39 \pm 2.71$ & 0.943 \\
\hline
\end{tabular}

Table VI: Comparison of anthropometric variables among four fitness groups

\section{B) Cardio-respiratory variables}


Resting cardiorespiratory variables; SBP, DBP and RR showed no significant differences when comparison was done among the four fitness groups but showed significant differences with resting PR (table VII).

\begin{tabular}{|c|c|c|c|c|c|c|}
\hline \multirow[b]{2}{*}{ Variables } & \multicolumn{4}{|c|}{ Groups (Mean \pm SD) } & \multirow[t]{2}{*}{$\begin{array}{l}\text { Overall } \\
\text { p-value }\end{array}$} & \multirow[t]{2}{*}{ p6 } \\
\hline & $\begin{array}{c}\text { Good } \\
\text { fitness } \\
\text { level } \\
(n=9)\end{array}$ & $\begin{array}{c}\text { Satisfactory } \\
\text { fitness } \\
\text { level } \\
(n=17)\end{array}$ & $\begin{array}{l}\text { Poor } \\
\text { fitness } \\
\text { level } \\
(n=12)\end{array}$ & $\begin{array}{c}\text { Very poor } \\
\text { fitness } \\
\text { level } \\
(n=19)\end{array}$ & & \\
\hline $\begin{array}{c}\text { SBP } \\
(\mathrm{mm} \mathrm{Hg})\end{array}$ & $\begin{array}{l}112.44 \\
\pm 8.29\end{array}$ & $\begin{array}{c}113.18 \pm \\
8.92\end{array}$ & $\begin{array}{c}111.17 \pm \\
6.63\end{array}$ & $\begin{array}{c}111.89 \pm \\
12.55\end{array}$ & 0.955 & \\
\hline $\begin{array}{c}\text { DBP } \\
(\mathrm{mm} \mathrm{Hg})\end{array}$ & $\begin{array}{c}73.11 \pm \\
8.49\end{array}$ & $\begin{array}{c}75.76 \pm \\
12.82\end{array}$ & $\begin{array}{c}73.50 \pm \\
8.05\end{array}$ & $\begin{array}{c}70.89 \pm \\
6.78\end{array}$ & 0.511 & \\
\hline $\begin{array}{l}\text { Resting PR } \\
\text { (bpm) }\end{array}$ & $\begin{array}{c}72.00 \pm \\
9.29\end{array}$ & $\begin{array}{c}68.35 \pm \\
5.95\end{array}$ & $\begin{array}{c}75.67 \pm \\
6.88\end{array}$ & $\begin{array}{c}78.89 \pm \\
7.67\end{array}$ & $0.001^{*}$ & $0.001 *$ \\
\hline $\begin{array}{c}\text { RR } \\
\text { (breaths/ } \\
\text { min) }\end{array}$ & $\begin{array}{c}17.00 \pm \\
1.32\end{array}$ & $\begin{array}{c}17.35 \pm \\
2.45\end{array}$ & $\begin{array}{c}17.42 \pm \\
1.17\end{array}$ & $\begin{array}{c}16.89 \pm \\
2.16\end{array}$ & 0.859 & \\
\hline
\end{tabular}

\section{Table VII: Comparison of cardiorespiratory variables among four fitness} groups

\section{DISCUSSION}

A cross sectional study was conducted on 57 apparently healthy young medical students. In present study medical students were categorized into four fitness groups: Good, satisfactory, poor, very poor based on recovery heart rate obtained after 3-Minutes Step Test. For the group division, YMCA guidelines were followed with some modifications. Physical fitness index included recovery heart rate.In present study all students were in young age group, male and female students were in equal proportion. All students were lean (Table IV). Their SBP, $\mathrm{DBP}$, pulse rate and respiratory rate were within normal limits (TableV).

We found that in total number of medical students taken for the study, 9 students fell in good category, 17 in satisfactory, 12 in poor and 19 in very poor categories. A similar study conducted by Richa and colleague (10), 2015 found that scoring of the physical fitness of most of Physiotherapists assessed using YMCA 3-Minute Step Test fell in the category of poor and below average which had similar results with our study proving that medical students had sedentary life style. They were recommended to do regular physical activity to improve their cardiovascular fitness.

\section{Anthropometric variables among four groups}

The four groups anthropometric variables were taken. The study found that there were no significant differences among different groups of fitness in terms of anthropometric variables which included age, height $(\mathrm{m})$, weight $(\mathrm{kg})$ and $\mathrm{BMI}\left(\mathrm{kg} / \mathrm{m}^{2}\right)$.
Similar, study was conducted by Akre and Neha, 2015 (5) found out correlation between PFI and BMI. And found that PFI depended on recovery heart rate after exercise which had negative correlation between PFI with BMI. The age groups of our study were similar so for that reason there were not significant difference in terms of BMI. Our result didn't show any significant difference, it may be because in the present study all included students were residential.

\section{Cardiorespiratory variables among four groups}

Our study showed all the four levels of fitness groups (good, satisfactory, poor and very poor) were comparable in terms of their SBP, DBP and respiratory rate except resting pulse rate. Resting pulse was significantly high in very poor fitness group as compared to satisfactory group.

\section{LIMITATIONS}

$\mathrm{VO}_{2}$ max was not measured directly, it was calculated using derived formula. The number of students in some sub-groups were less and overall sample size of this study was also relatively small. Similar study could be done with more number of students for better results.

\section{Future Directions}

The study can be conducted on larger sample size both including male and female as separate groups and in different age groups.

\section{CONCLUSION}

All anthropometric and cardiorespiratory variables were comparable among four fitness groups, except resting heart rate. The resting heart rate increased in very poor fitness group compare to satisfactory fitness group in both male and female students.

\section{REFERENCES}

1. Caspersen C, Powell K, Christenson G. Physical activity, exercise, and physical fitness: definitions and distinctions for health-related research. Public health reports. $1985 ; 100(2): 126-31$

2. Jyoti P.K, Gopal B.D, Shri-laxmi B, Lata M.M, Manjunath A. Status of Physical fitness index percent and anthropometric parameters in residential school children compared to nonresidential school children. Journal of Krishna Institute of Medical Sciences University. 2012; $1(2): 137-141$.

3. Hanna K M Hkm A, Ronaldo V T Ruth F Rf S, Ricardo C, Orlando F A B, Marco Túlio De M. Reviewing on physical exercise and the cognitive function. Revista Brasileira de. 2006;12(9): 97-103.

4. Bagadel A, Bhonde M, Nikam L. Cardiac response to 
exercise determined by physical fitness index in young obese and normal-weight medical students. Indian Journal of Basic and Applied Medical Research. 2015; 4(2): 389-393.

5. Akre A, Neha B. Co-relation between Physical fitness index and body mass index in asymptomatic college girls. Journal of Exercise Science and Physiotherapy. 2015; 11(2):129.

6. Brouha L, Fradd N W, Savage B M. Studies in physical efficiency of college students. Research Quarterly. 1944;15: 211-224.

7. Mather M. Aging and cognition. Wiley Interdisciplinary Reviews: Cognitive Science. 2010; 1(3):346-362.

8. Royall D, Lauterbach E, Kaufer D, Malloy P, Coburn K, Black K. The cognitive correlates of functional status: A Review from the Committee on Research of the American Neuropsychiatric Association. Journal of Neuropsychiatric. 2007;19(3):249-265.

9. YMCA Bench step test cardiovascular fitness Available from https://thehubedu-production. s3.amazonaws.com/uploads/3/fd00fae8-7453-45bf96bb-705135c0ba27/ YMCA Bench Step Test for Cardiovascular Fitness.pdf.

10. Richa R, Chugh P, Negi M P S.A study on cardiovascular fitness of sedentary college students. International Journal of Science and Research (IJSR). 2015 June; 4(6):109-111. 